\title{
The Recognition Of The Independence Of Azerbaijan Democratic Republic In Paris Peace Conference And The Attitude Of Iran
}

\author{
Shabnam Yusifova \\ Azerbaijan National Academy of Sciences, doctoral \\ shebnem-yusifova@mail.ru
}

DOI:10.5901/mjss.2014.v5n19p355

\begin{abstract}
This article deals with the activity of Azerbaijan Democratic Republic, which declared its independence on May 28, 1918 and the relations with the neighboring states, especially, Iran in Paris Peace Conference. In the introduction the political situation in Azerbaijan and Iran after the First World War, Persians' hesitant attitude towards Azerbaijan and its causes, the preparation process of the representatives of the government of ADR for the Paris Peace Conference are discussed and the relations between Azerbaijan and Iran are divided into the periods. It is known that after the collapse of Tsarist Russia, the trends of independence started growing in the South Caucasus. Recognition of the independence by the neighboring states and the international community became the most important issue in foreign policy of ADR. Paris Peace Conference which was convened after the First World War opened up the opportunities for the government of Azerbaijan in the solution of this problem. In the conference Azerbaijan-Iranian joint commission was established and the agreement which consisted of four points was signed. As the result of strenuous activity of Azerbaijan representatives, the independence of the ADR was recognized by the international community on January 11, 1920 in Paris Peace Conference. Iran, which normalized the relations with Azerbaijan in Paris Peace Conference, according to the friendship treaty that was signed on March 20, 1920, declared that they recognized the independence of Azerbaijan.
\end{abstract}

Keywords: independence, recognition, Azerbaijan Democratic Republic, Iran, Paris Peace Conference

\section{Introduction.}

Defeats in World War I and the escalation of internal situation in Russia had led to a deep political crisis. As a result of the February Revolution of 1917, Tsarist Russia came to an end. The Romanov family, who had ruled Russia since the seventeenth century, was overthrown and put an end to monarchy. The overthrow of the Czarism in the South Caucasus, as well as in other colonies of Russian, caused an increase in the tendency of independence.On 28 May 1918, Azerbaijan declared its independence. The government officials of ADR which announced the establishment of an independent state of Azerbaijan to whole world via radio-telegraph since this date began to take its first steps in the field international relations. Recognition of independence both by neighboring states and international community was the most important purpose in front of the fledgling state. The declaration of sovereignty of Azerbaijan appeared at a time when the political situation was intense in the world. So, the First World War had just ended and the winning countries decided to summon a peace conference in order to solve the subsequent fate of the world and regulate relations with the defeated countries (Germany, the Ottoman Empire, Bulgaria and Austria-Hungary). It was very important to participate in the peace conference for recognition of Azerbaijan in the international arena. For this the government began to take the first diplomatic steps and tried to mend relations with neighboring states Turkey, Iran, Georgia and Armenia.

In this time the political situation was much more complicated in Iran. During World War I the territory of Iran had become military operations area. Although Iran proclaimed neutrality in the war, several battles were fought in western Iran between Russian and Ottoman forces. Those battles were major blow to the economy of Iran and led to starvation among the population. The troops of Russia had occupied the northern part, England the southern part and Turkish-German troops the western part of the country. (Olson Wm. J. 1984) After the war, Iran stayed as a semi-colonial of United Kingdom, here the Anglophile government led by Vosuq od-Dowleh was established. At the same time Azerbaijan that declared its independence in the north from Iran, was trying to establish bilateral relations with the neighboring states. On this basis, it was very important to create bilateral relations with Iran.

Generally, ADR-Iran relations conventionally divided into 3 periods: 
From May 28, 1918 to spring of 1919. At this stage Azerbaijan repeatedly appealed to Iran for the recognition of independence and establishment of diplomatic relations between two states, but Iran refused to recognize Azerbaijan as Independent Republic.

From the spring of 1919 to the end of the same year. During this period negotiations between Azerbaijan and Iran were proceeding in Paris Peace Conference. The change occurred in Iran's attitude toward Azerbaijan and Azerbaijan-Iran joint commission was established.

From January to April 1920. At this stage, the Azerbaijani-Iranian relations reached its peak. Azerbaijan was de-facto recognized by the international community, as well as, negotiations with Iran at conference resulted in successfully. On 20 March 1920, Iran became the first country that recognized Azerbaijan de-jure.

\section{Methods}

To thoroughly investigate this research question was used a comparative-historical method.

\section{Materials}

The materials of the State Archive of Azerbaijan Republic, the research works of Azerbaijan, Russian, English and Persian and the sources of the same period were used in this article.

\section{Procedure}

This study was approved by the Department of International Relations of the National Academy of Sciences of Azerbaijan.

\section{The importance of this article}

The main aim of this study is to investigate the activities of ADR in Paris Peace Conference and international relations between Azerbaijan and Iran from 1918 to 1920. The research of article helps us to learn Azerbaijan-Iran relations in contemporary time.

\section{The activities of Azerbaijan in Paris Peace Conference and Iran}

The government of Azerbaijan demonstrated the intention to forge friendly relations with all nations and states, including neighboring states by means of the Declaration of Independence adopted on May 28. First of all, ADR determined 4 main directions of foreign policy strategy:

To live in the condition of peace and kindly neighborhood with the South Caucasus countries and the establishment of comprehensive relations.

Establishment of normal diplomatic relations with the independent republic and governments which formed in Russia and Ukraine.

The recognition of the independence of ADR by European countries and the establishment of formal diplomatic relations.

To build the political, economic and cultural relations with neighboring Iran and Turkey. (Nəsibli Nəsib. 2011)

In order to achieve the consecutive goals, the government of ADR managed to sign the treaty with Turkey on friendship, cooperation and mutual military assistance on June 4, 1918. At this time, the representatives of ADR appealed to the Consulate of Iran and asked the recognition of state's sovereignty. But the Iranian Consulate rejected this appeal, the Council sent the declaration of Azerbaijan representatives back and said that didn't recognize the sovereign government under the name of Azerbaijan, even claimed that the historically lands of Azerbaijan belong to Iran. (SAAR, I 10, w 31) Nevertheless, the steps of Iran didn't discourage Azerbaijan representatives and on the contrary they persistently began to struggle for recognition of young state.

To forge a relationship with only neighboring states was not enough for the government of Azerbaijan to continue its independence. To be recognized by the world's great powers became the utmost priority of Azerbaijan government. In order to achieve this goal, it was very important to participate in Paris Peace Conference. There were a lot of stumbling 
blocks to implement the struggle for the recognition of Azerbaijan. According to the Mondros reconciliation, Ottoman troops left Azerbaijan and on November 17, 1918 the Allies' army led by General William Thomson came to capital Baku. Despite all the propaganda of Armenian and Russian against Azerbaijan, Gen. Thomson declared that he respected highly the government of Azerbaijan, it's prime minister and that its government would be the only legal power in the country on December 28. (Həsənli Cəmil.2009) Finally, at the meeting of the Azerbaijani Parliament, it was decided to create a large staff was for attending in Paris Peace Conference on December 7. On December 28, the structure and the plan of action of diplomatic staff which had to be sent to conference were determined. The speaker of Parliament, Ali MardanTopchibashov appointed a leader of delegation. The delegation first arrived in Istanbul and began to deal with visa problem. But the visa problems caused to be late of Azerbaijan representatives to Paris Peace Conference. In November 1918, during negotiations with General Thomson the commander of the Allies in Enzeli, he pledged the participation of Azerbaijan representatives in the conference. After a while, Entente troops under command of General Thomson entered the city of Baku. Both General Thomson and the commander of the British troops in the Balkans and Caucasus, George Milen repeatedly told representatives of Azerbaijan government in their statements that all questionable issues would be solved in peace conference. During the conference a special committee was organized for learning social, economic and political situation in the south of Russia. The committee was divided into 3 parts, one of them was exactly assigned for Caucasus. Another purpose of the staff was to analyze the demands made by the Caucasian states in Paris Peace Conference. For this purpose General Moore who led the Caucasian delegation put some questions to Azerbaijan representatives.

Can Azerbaijan survive as an independent republic from political and economic point of view?

Do you have sufficient material and moral strength for independence?

Can a federation or a confederation be established in the Caucasus or Transcaucasia?

If the Russian Federative Republic is created, would Azerbaijan consider joining this federation?

Do you assume a possibility of being taken under auspices of any other state? (Hasanli Jamil 2014)

The Azerbaijan delegation answered to the questions that they gained independence from Russia and had material and spiritual strength for maintaining steady and eternal independence. Regardless of the existence of any structure in Russia, Azerbaijan categorically refused to be a part of it. The establishment of a confederation in Caucasus was impossible because of hostile attitude and claim of the Armenians on Azerbaijan and Turkish lands.

there was an issue to accept the guardianship of any state, Azerbaijan representatives declared that they partially preferred America. On condition that America would fulfill the 14 principles of Woodrow Wilson and there was no economic interest to Azerbaijan.

In spite of the conference opened on January 18, 1919, the Azerbaijan representatives arrived in Paris in mid-May after three month of intense diplomatic and political struggle. The members of delegation achieved to meet the president of US, Woodrow Wilson. For the first time, the Azerbaijan issue was discussed at the Council of Allied Powers at the suggestion of Woodrow Wilson among the United States, France, England and Italy on May 2, 1919. At the meeting it was decided to let the newly independent Caucasian states express their views. Finally, on May 28 the meeting of Azerbaijan representatives with Woodrow Wilson took place. This meeting took place on a significant date, because a year ago on May 28, 1918 Azerbaijan had gained its independence. During the first half of the day AlimardanTopchubashov met a member of the US delegation Henri Morqentau who was ambassador of US in Turkey during the war and some important issues were discussed between them. During the second half of the same day, the representatives of Azerbaijan were adopted by the president of US Woodrow Wilson. During the meeting, the head of the Azerbaijan delegation A. M. Topchubashov presented memorandum to Woodrow Wilson containing the detailed information about Azerbaijan. 6 clauses were proposed in memorandum.

That the independence of Azerbaijan be recognized by the members of the Paris Peace Conference.

That the Azerbaijani delegation be admitted to the Paris Peace Conference.

That Wilsonian principles be applied to Azerbaijan.

That Azerbaijan be admitted to the League of Nations.

That the United States War Department extend military help to Azerbaijan.

That diplomatic relations be established between the Republic of Azerbaijan and the United States of America. (Bulleten 1920) 
At the same time, AlimardanTopchubashov also said that if these demands were accepted, Azerbaijan would pay off the debts of Russia which were given when Azerbaijan was within Tsarist Russia. However, in spite of all the efforts of Azerbaijan side, Woodrow Wilson's response was not encouraging and he demonstrated hesitant position. He said that, the Conference didn't want decomposition of the world in small pieces and it would be better and convenient for Azerbaijan to establish a confederation of Transcaucasia could receive the protection of some Power on the basis of a mandate granted by the League of Nations. Woodrow Wilson also noted that, this issue could not be resolved before the issue of Russia. Despitethe negotiations didn't bring the expected results, this meeting was an important event for Azerbaijan side. Because the meeting of newly independent state's representatives with the president of US caused rise of reputation and at the meeting it was decided to send an American mission to the Caucasus. Woodrow Wilson also advised the representatives to present their demands in the peace conference.

Abiding by W. Wilson's advice the Azerbaijan representatives prepared booklet named "The demands of Caucasian Azerbaijan's peace representatives" during the conference. Booklet containing detailed information about Azerbaijan were translated in English and French and presented to other representatives of peace conference.(Tadeusz S. 2004) The demands of Azerbaijan delegation to Paris Peace Conference were also noted in document. The requirements were as follows.

Peace conference must approve the separation of Caucasian Azerbaijan from Russia which declared itself independent under the name of ADR.

The representatives of Azerbaijan Republic must participate in the Peace Conference and be involved its activities.

Azerbaijan Republic must be selected a member to the League of Nations as well as other states.

The representatives of Iran were also participating in Paris Peace Conference, but there were some misunderstandings in the relations with them. During the meeting held in the conference it was decided that negotiations about establishment of bilateral relations with Iran will continue in outside the peace conference. In the spring of 1919, a special delegation led by Ismail Khan Ziatkhan was sent to Iran. Ismail khan arrived in Tehran in April 1919 and held a series of meetings with Iranian officials. In spite of negotiations between two states ended the signing of the agreement which consisted of 14 items, the treaty was exposed to pressure and was not endorse. (SAAR, 970, I 1, w 98) Azerbaijan Republic increased effort for rectification of relations and decided to establish a new diplomatic mission in Iran on July 16, 1919. Adil khan Ziatkhan was elected the head of the delegation to Iran. Etter, the Tsarist Russian's former ambassador to Iran protested the arrival of Azerbaijan representatives at Iran and tried to prevent the establishment of relations. But this time Russia's influence in Iran was weak and his protest was not given the importance. Azerbaijani delegation was greeted very frankly by the Iranian government, even Adil khan was received by the Shah of Iran.

After the establishment of diplomatic relations between Azerbaijan and Iran, talks were continued in Paris. When Aligulu M. Ansari appointed head of the Iranian delegation to Paris Peace Conference on his way to Europe, he was in Baku, met with the delegation of Azerbaijan and suggested organization of confederation of Azerbaijan and Iran. Iranian Foreign Minister related this demand to various reasons.

He noted that the victorious Entente would not meet positive to the signing contract of Azerbaijan with Turkey which was defeated in World War I and supporting of two countries each other in foreign policy. The independence of Azerbaijan will be not recognized by the international Community.

According to hostile attitude and territorial claims of Armenia against Azerbaijan, the creation of the federation of South Caucasus is impossible.

Another reason is existence of Russian threat from North. In such circumstances, it is advisable to create Azerbaijan-Iran confederation.

However, Azerbaijan delegation had rightly objected to this demand. It is true that as a result of the creation of the confederation Azerbaijani lands could be combined. Because the contracts of Gulistan (1813) and Turkmenchay (1828) were concluded between Russia and Iran, divided Azerbaijani lands into two parts- northern and south Azerbaijan. On the other side, this offer may be dropping enslave of Azerbaijani lands again which newly acquired independence. Therefore, the suggestion of the creation federation was rejected.

Azerbaijani delegation confronted some difficulty associated with the territorial claims of Iran in Paris Peace Conference. Iranian delegations informed that the Tsarist Russia had already destroyed, therefore, the contracts of Gulistan and Turkmenchay concluded with the Russian Empire has been violated. They claimed that northern territories of Azerbaijan 
that formerly was under the authority of Tsarist Russia but now gained independence historically belongs to Iran. The Iranian government considered that the time had came to reclaim from a weak Russia those territories that Iran had lost in the past to a strong Russia and all these territories must annex to Iran. An Iranian delegation was sentto Paris under the leader of Foreign Minister Mushavar ul-Mamalek,in order to present claims before the Peace Conference. It was refused admission on the ground that Iran was not a member of allied and associated nations. Nonetheless, the Iranian delegation formulated far-reaching demands, in which the salient points were the annulment of all foreign concessions, the abolition of capitulations, compensation for wartime damages perpetrated on Iranian territory, and the inclusion within the boundaries of Iran of Transcaspia, Merv and Khiva up to the Oxus River, of several districts in the Caucasus, including Nakhichevan and of the Kurdish area of Mesopotamia as far as Euphrates. However, the territorial claims of Iran which has no specific role in the World War I were rejected by representatives in Peace Conference. (Lengrowski G. 1949) After the Treaty of August 9, 1919 the participation of Iranian delegation was not allowed in Conference. The Shah's government decided to send a new delegation under the leadership of Firuz Mirza to Paris. After the arrival of Firuz Mirza in Paris, the situation has changed completely.

\section{Analysis}

Iran protested the recognition of Azerbaijan's independence in the initial phase of Azerbaijan-Iran relations. What are the reasons of this? It is known that the World War I had just ended, Tsarist Russia was destroyed, the nations of South Caucasus had been seperated from Russia and had gained independence. In such indefinitely time Iran tried unlocking of the course of events, hesitated relations with Azerbaijan. That is why, S. Z. Tabatabaee was appointed the chief of Caucasian extraordinary staff. Because, Tabatabaee had worked as a representative of Iran during 2 years and could better anlyze political processes in Russia.

The decision to use the name "Azerbaijan" drew some protest from Iran. Because, according to the treaties were concluded between Russia and Iran in 1813 and 1828, the lands of South Azerbaijan were subordinates of Iran and Iranian government was afraid that the newly formed state would combine the South Azerbaijan to itself and would create a unified state under the name of Azerbaijan. At such time the entering of Ottoman troops into the area of South Azerbaijan began to worry Iran even more. Iran became anxious that Tabriz province might be taken back from Iran and combined to Caucasian Azerbaijan with the helh of Ottoman troops. For ending these claims of Iran, the heads of Azerbaijan Republic began to use expression of Caucasus Azerbaijan in diplomatic documents.

Iran is also faired that events taken place in Northen Azerbaijan could influence to South Azerbaijan and then this probability justified itself in the liberation movement led by Khiyabani in 1920. In the summer of 1918, Mammed Emin Resulzadeh, the leader of Azerbaijan Republic informed that he often met with Iranian Azerbaijanis in Istanbul.

"They are my old friends. I felt their secret love and passion for the sovereignty of Azerbaijan... most of them had lost their hopes concerning Iran and have their own ideas. The Southern Azerbaijanis have created their own society here based on Turkism and Azerbaijanism. They think we are forgetting them."( Rəsulzadə М. Ә. 2013)

Afterwards Adil khan Ziyadxanli the diplomatic ambassador of Azerbaijan in Iran wrote in the letter dated April 11.

"The Turks of Iranian Azerbaijan are showing signs of brotherly friendship. Iranian Azerbaijan is hoping to gain autonomy, independence and secession from Farsistan."(SAAR 970, I 1, w 98)

The other reason of escalation of relations between the two neighboring states was standing in position against improvement of Azerbaijan-Iran relations. Thus, both Russia and United Kingdom had its own plans about Caucasus and Iran. Even Russia became anxious dispatching delegation of Iran to Caucasus and sent protest to Iran's Foreign Ministry. England which took control the Iran's military, financila, communications and other areas with the treaty of Avgust 9, 1919 intervened the relation of Azerbaijan-Iran, the lettes of Iranian representatives that were send from Baku to Tehran were captured and read.

But after the arrival of Iran's new foreign minister Firuz Mirza as the leader of Iranian delegation to Paris the significant changes in relations happened. There were some factors that caused improvement of relatons.

While going to Europe passing from Azerbaijan and the meeting of shah of Iran with the representatives of Azerbaijan government in Baku played a crucial role in the warming of relations.(SAAR 2598, I 1, w 2)

Caucasus especially Iran was the way to the west for Iran and the transit loads, postal service passed exactly from this. Iran feared that if did not recognize the independence of Azerbaijan, might be deprivedtrade via Azerbaijan. The 
government of Azerbaijan was also interested in establishing trade relations with Iran. The ambassador of Azerbaijan in Turkey Yusif Vezir Chemenzeminli informed in his letter.

"We would like to strengthen Iran's economy. Because it's products will be traansported via Azerbaijan to other countries and we will benefit from it." (Çəmənzəminli Y. V. 1994)

In addition it was an important factor establishing state against Russia in Caucasus for Iran. Azerbaijan played the role of buffer state between Russia and Iran. If Iran recognized the independence of Azerbaijan achieve bulwark for itself against Russia.

The Muslim factor is very important in improvement of relations. The leader of ADR, M. E. Rasulzade informed in his letters that establishing powerful independent republic in Caucasus must be rejoice the government of Iran in fact.

The changes in the relations between Azerbaijan and Iran

The Anglo-Iranian agreement which was concluded on August 9, 1919 had an impact on the relations between Azerbaijan and Iran. This treaty provided for Britain to supply, at a cost to Iran, administrative advisers, officers, munitions and equipment for the formation of a uniform military forces; to assist in the construction of railways and a revision of customs tariffs; to cooperate in the collection of war compensation from belligerent parties; and to lend Iran 2 million at 7 percent annual interest. Instead of this, Britain obtained a monopoly in supplying administrative advisers as well as military experts and equipment, and Iran's customs' revenues were pledged to repay the loan. (Алиев С. М. 2004) At this time the threat of bolshevism strengthened in Iran. Therefore, to take control of security into the hands of British was favorable to Iran. British wanted to strengthen the control over its colonies in the Near and Middle East and at the same time, to destroy the growing threat of Bolshevism. The agreement which depended itself economically and politically on England was meet with protest both within and outside the country. Entente countries, including the US deprived Iran from attending in Paris Peace Conference. The Iran's delegation in Paris was canceled and it was decided to change the composition of the committee.

A new delegation organized under the lidership of Iran's new foreign minister Firuz Mirza was sent to Europe in September 1919. After that, a complete breakthrough took place in relations. Firuz Mirza made a statement that Iran did not have any claims on the land of Caucasian Azerbaijan, even told would help Azerbaijan for directing England attention to it.

Azerbaijani delegation also tried to take advantage of the British assistance to Iran. Thus, as a result of the activities of both countries' representatives, Azerbaijan-Iranian joint commission was established at the end of October, 1919. Ceyhun bek Hacibekli and Mir Yakub Mehdiyev was selected to commission by Azerbaijan side and Zekov Mulk, Mustan SarisSeltene by Iranian side. The commission held its first meeting on 29 October and agreement consisted of 4 points was signed between Azerbaijan and Iran. The terms of the agreement were as follows.

Regardless of establishing any power and structure of state in Russia, Caucasian Azerbaijan with the boundaries which was reflected in the map and requisition submitted to Paris Peace Conference, decompose from Rusia for ever.

ADR was established through the general election and is known as presidential, parliamentary, independent and democratic republic. The capital of Republic is Baku.

ADR establishes political and economic relations with Iran in foreign affairs. This relationship is defined by mutual consent of both countries. The consolidation of activities of both countries is desired.

Azerbaijan need the help of United Kingdom in order to achieve the aim mentioned in the previous terms, recognition of independence, protection of any kind of encroachment, security of state, the political, economic, cultural and military development. (АДР - Внешняя политика. 1998)

The most important issue was noted in the fourth terms. According to Anglo-Iranian Treaty of August 9, 1919 United Kingdom had to help Iran. Azerbaijan representatives wanted the same help. But Iran tried to use this desire of Azerbaijan. So, for this purpose Firuz Mirza wrote a letter to British Foreign Minister Lord Cerzon and asked him to take into account the Iran's interests in Caucasus, especially in Baku. (Mədətli E. 2011)

\section{Results}

Finally, it should be noted that the negotiotions between Azerbaijan and Iran resulted successfully in Paris Peace Conference and the delegations of each two countries began to continue talks in outside the conference. The head of Iranian delegation Firuz Mirza proposed sending a special committee to Caucasus in his letter that written to Iranian Foreign 
Minister. At last, Caucasian Extraordinary Delegation under the lidership of S. Z. Tabatabaee was created and sent to Azerbaijan at the end of 1919. On 5 December the meeting of Azerbaijan-Iran Joint Commission took place and brought to attention that there was not only economic and political relations, but also the cultural and religious similarities between two country, a lot of factors combine them, therefore it is important to develop the relationship further.

In addition, Azerbaijani delegation has achieved great success in Paris Peace Conference. Thus, on 11 January 1920, at the suggestion of British Foreign Secretary Lord Curzon, the independence of Azerbaijan and Georgia was known defacto by international unity in the assembly of the Supreme Council of the Paris Peace Conference on 11 January 1920. On January 15, the representatives of Azerbaijani and Georgian were invited to French Foreign Ministery. The formal decision of Paris Peace Conference about recognition of Azerbaijan was presented to the head of ADR's delegation A. M. Topchubashev in the meeting taken place with the participation of French Foreign Ministry's secretary Jules Cambon, representatives of Britain and Italy, Philipp Kerr and Marke de la Torreta. On March 5, 1920 Azerbaijan delegation successfully completed its mission in Paris Peace Conference and was canceled. (Quliyev V. 2008) According to the decision of the parliament in April 1, the delegation expanded its activities and began to increase the efforts for the establisment of diplomatic missions in France, Britain, Italy, the United States and Poland. At the same time, embassies of various countries were opened in Baku, the capital of Azerbaijan. The recognition of Azerbaijani independence was celebrated with special festivities in capital Baku. On January 14, the diplomatic representatives of foreign countries, including the head of Caucasian Extraordinary Delegation S. Z. Tabatabaee took part in the meeting of Azerbaijani Parliament and said that Iran soon would recognize the independence of Azerbaijan. At the end of 1919, talks held both in Baku and Tehran, yielded its successful outcome. On March 20, 1920 the treaty consists of 4 points was signed between Azerbaijan and Iran. The terms of the agreement were as follows.

Iranian shah's government declared that Iran formally recognize the independence of Azerbaijan.

In order to intensification of friendship and stability of economic relations between two states, contracts about trade and customs, consular, postal, telegraph and etc. must conclude. Via this agreement, the rights of representatives and citizens of both states have been to determine.

For international relations, the special representation-embassy of Caucasian Azerbaijan Republic and Iran will be open in Tehran and Baku.

After signing, contract will be approved by the heads of both countries during a month. (AXC ensiklopediya 2004)

According to the treaty, the diplomatic representations was opened both in Baku and Tehran and Adil khan Ziatkhanli was selected ambassador of Azerbaijan in Iran. In the opening of Azerbaijan-Iran conference S. Z. Tabatabaee and Mammed Yusif Jafarov made speech and noted the importance of consolidation of economic and political relations between two countries after this. Ongoing negotiations between Azerbaijan and Iran resulted in the signing of agreements on postal, telegraph, trade, customs, judicial, transit and consular convention.

\section{Conclusion}

Azerbaijan Republic existed for 23 month and during this time achieved success, established diplomatic relations with neighboring states, created embassies. As a result of active foreign policy, ADR achieved the recognition of independence by both the neighboring states and international unity. However, the subsequent ongoing of events took place against ADR. Since the beginning of 1920 , the political situation was extremely tense in the country. The main reason of this was already the activation of Soviet Russia and beginning to intrude the internal affairs of Azerbaijan. Since the declaration of independence, Azerbaijan tried to create diplomatic relations with Russia, but Russia rejected all attempts made by ADR for establishing diplomatic relationship between two countries. Even on January 11, 1920 the recognition of Azerbaijan by the Entente countries could not prevent Soviet threat. The aggressive attitude of Soviet Russia towards Azerbaijan was reflected in Lenin's telegram to the member of the Military Revolutionary Council of the Caucasus Front, Orjonikidze, sent on March 17, 1920.

\section{"It is very critical to capture Baku. Concentrate all your efforts on this." (Kazemzadeh F. 1951)}

On April 28, 1920 ADR was occupied by troops of Soviet Russia and they put an end to the country's independence. The Bolsheviks proclaimed the establishment of the Soviet Socialist Republic of Azerbaijan. Although the existence of ADR was less, it played a major role in the independence's history of Azerbaijani people. After the occupation, diplomatic relations between Azerbaijan and Iran was broken. When Azerbaijan was one of the parts of Soviet Union, the Iranian consulate 
was opened in Baku, 1971. And finally, after the collapse of Soviet Union, Azerbaijan Republic declared its independence in 1991 and the diplomatic relations between Azerbaijan and Iran were restored in 1992.

\section{References}

Алиев С. М. (1985) Нефть и общественно политическое развития Ирана в XX в. Москва, Наука.

Алиев С. М. (2004) История Ирана XX век. Москва, Ивранкрафтт.

Азербайджанская Демократическая Республика - Внешняя политика. (1998) Баку, Азербайджан.

Azərbaycan Xalq Cümhuriyyətinin xarici siyasəti, sənədlər məcmuəsi. (2009) Bakı, Garisma MMC.

Azərbaycan Xalq Cümhuriyyətinin ensiklopediyası. (2004) I cild. Bakı, Lider.

Bulletend'information de L'Azerbaidjan. (1920) No 7 January.

Çəmənzəminli Yusif Vəzir. (1994) Müstəqilliyimizi istəyiriksə. Bakı, Gənclik.

Həsənli Cəmil. (2009) Azərbaycan Xalq Cümhuriyyətinin xarici siyasəti 1918-1920. Bakı, Garisma MMC.

HasanliJamil (2014) Foreign policy of the Republic of Azerbaijan1918-1920.The difficult road to western integration. Sharpe, M.E. Inc.

Иванов М. С. (1985) История Ирана. Москва, Московского Университета

KazemzadehFiruz. (1951)The struggle for Trancaucasia 1917-1921. New York, Philosophical Library.

Lengrowski G. (1949) Russia and the West in Iran 1918-1948. New York, Cornell University Press.

Mədətli Eynulla. (2011) Azərbaycan həqiqətləri İran tarixşünaslığında. Bakı, Təhsil.

Nəsibli Nəsib. (2011) Azərbaycan Demokratik Respublikasının xarici siyasəti. Bakı. Qanun

NasrollahSaifpourFatemi. (1952) Diplomatic history of Persia 1917-1923. New York, Russell F. Moore Company

Olson Wm. J. (1984) Iranian relations during World War I. New York, Frank Cass Co.LTD

Гаджиев И. Б. (1958) Антисоветская интервенция Англии на Кавказе (1918-1920) Махачкала.

Quliyev Vilayət.(2008) Azərbaycan Paris sülh konfransında (1918-1920) Bakı, İndigo.

Rəsulzadə Məmməd Omin. (2013) Bakı və Azərbaycan tarixinə dair əsərlər(1918-1919). Bakı, Qanun.

The State Archive of Azerbaijan Republic, fund 2598, list 1, work 2, page 1-2

The State Archive of Azerbaijan Republic, fund 894, list 10, work 31, page 17-18

The State Archive of Azerbaijan Republic, fund 970, list 1, work 98, page 1

The State Archive of Azerbaijan Republic, fund 970, list 1, work 94, page 32

TadeuszSwietochowski. (2004)Russian Azerbaijan 1905-1920: the shaping of a national identity in a Muslim community. New York.Cambridge University Press.

\section{Supplements}



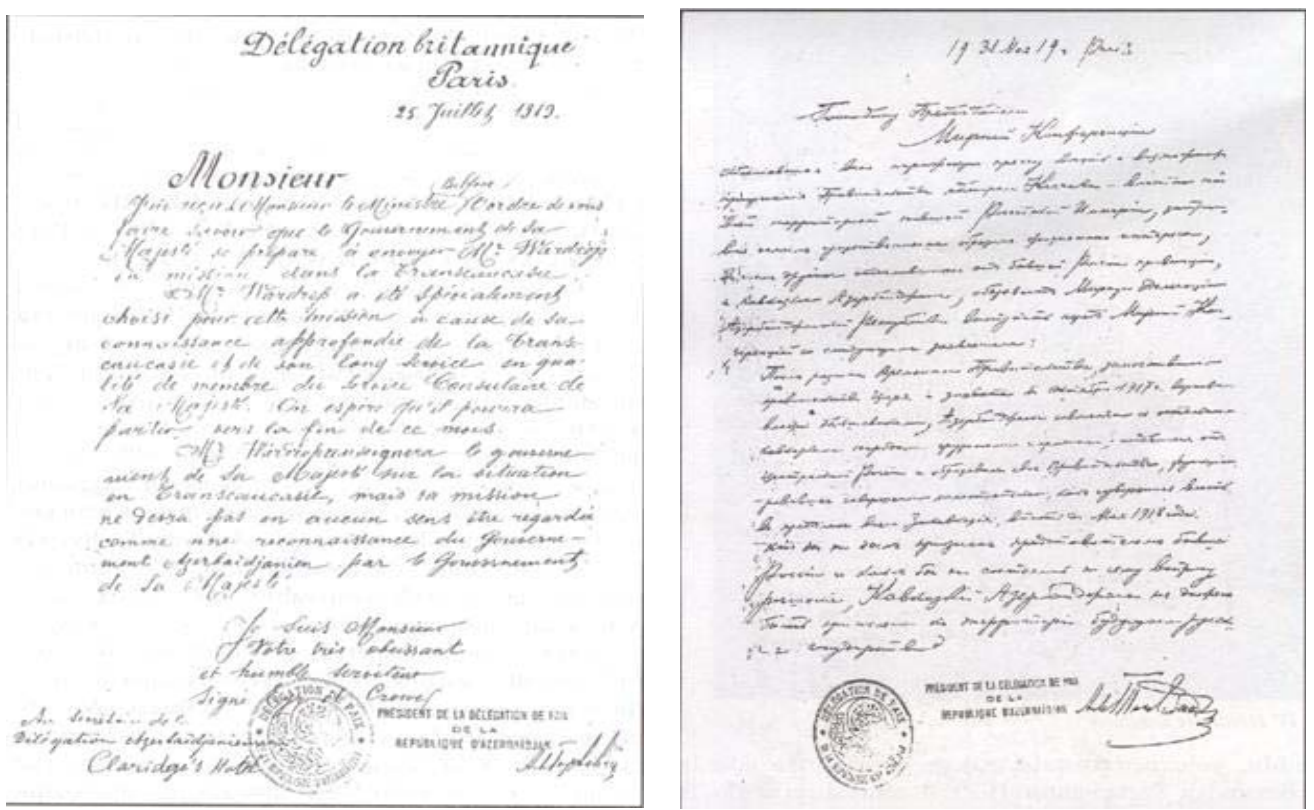

Topchubashov's letter to the Great BritainTopchubashov's letter to the chairman of the delegation at the Paris Peace Conference. Paris Peace Conference on the recognition of June 25, 1919. Azerbaijan's independence. May 31, 1919

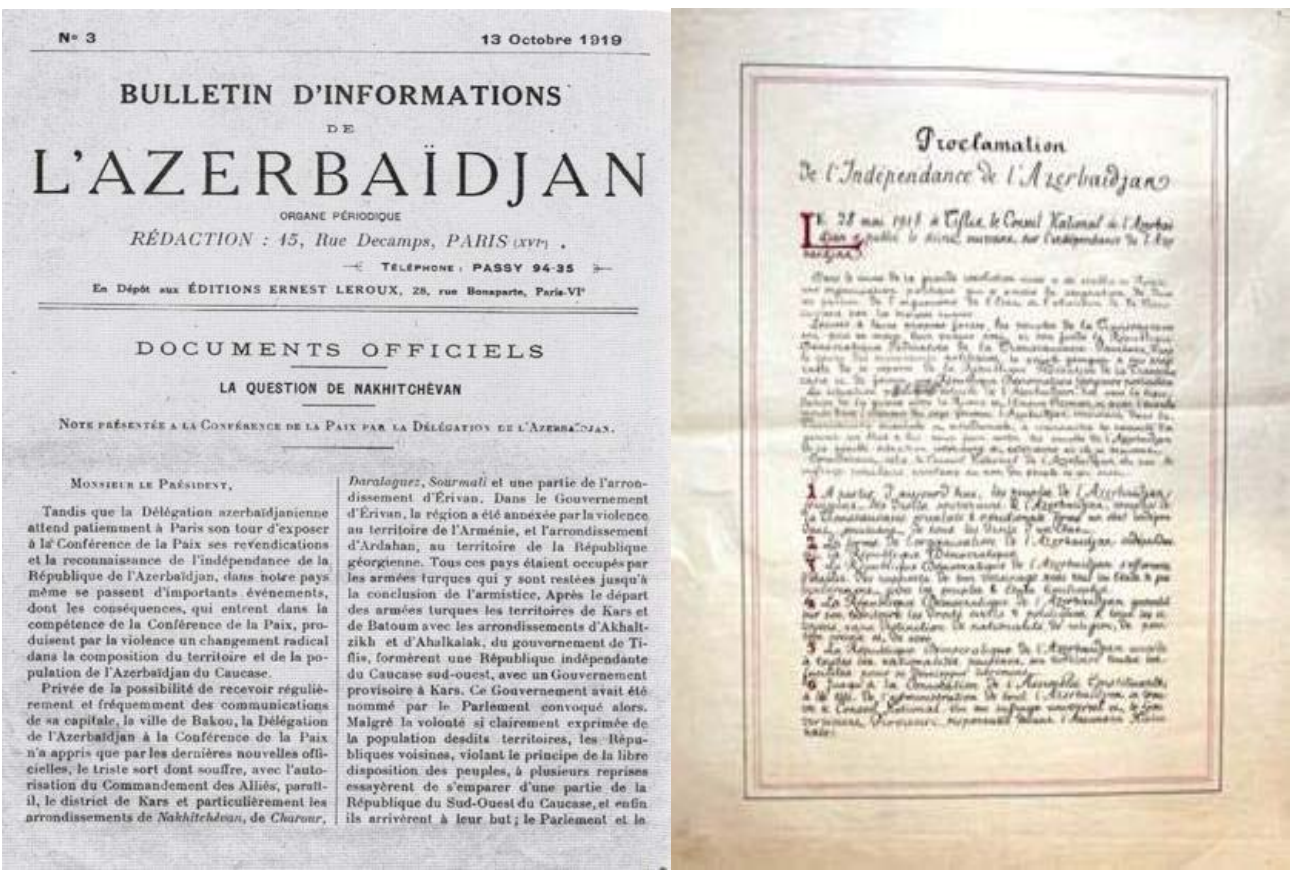

Azerbaijan information bulletin published by the The text of the declaration of independence

Azerbaijani delegation in Paris. October, 1919 in French 

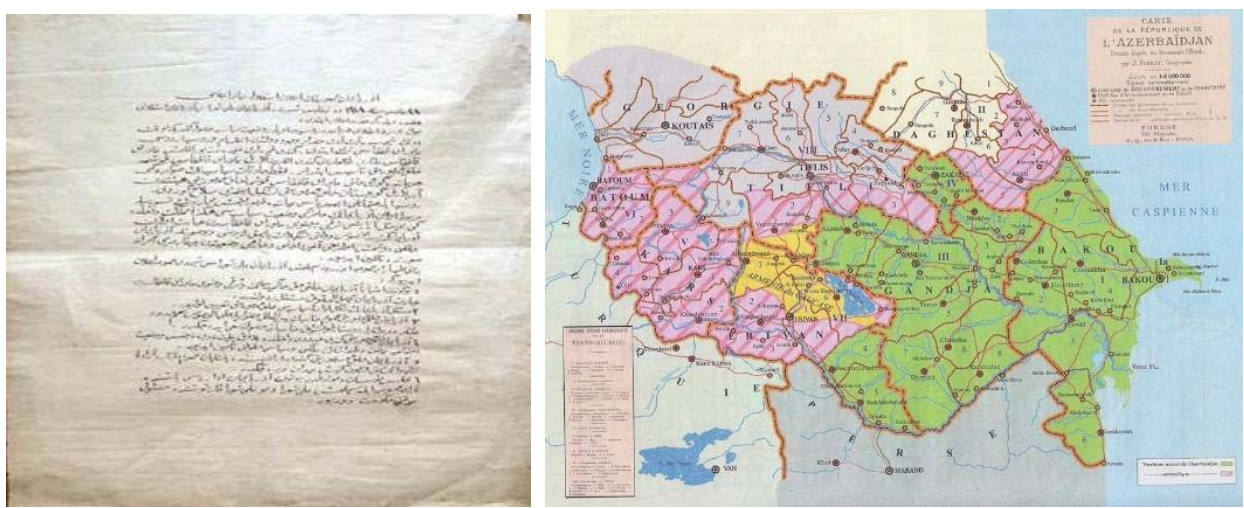

The map of Azerbaijan submitted to Paris Peace Conference

The text of the declaration of independence

\begin{tabular}{|c|c|}
\hline 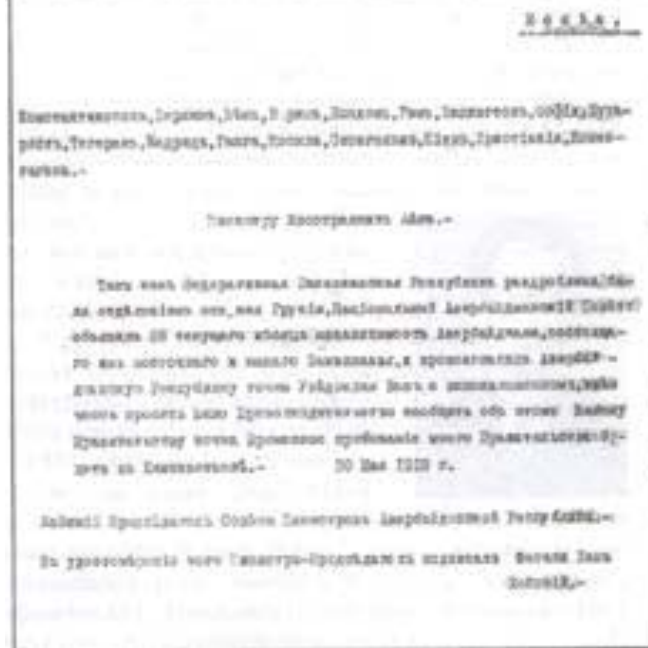 & 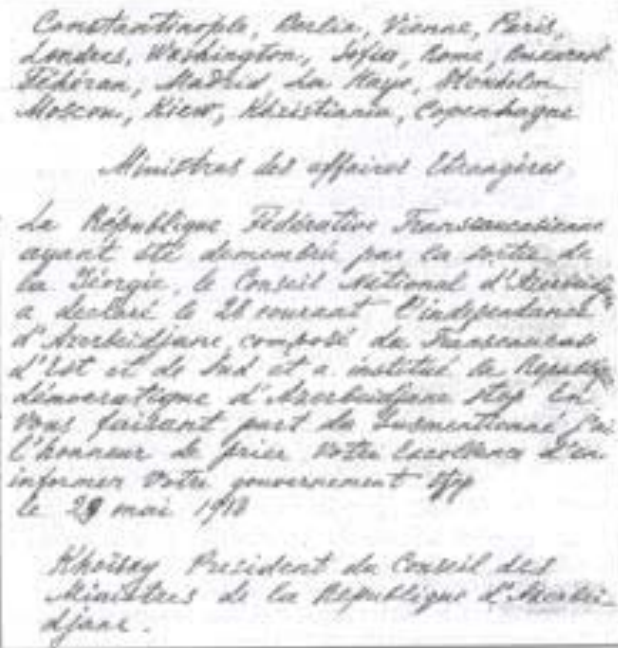 \\
\hline
\end{tabular}

Telegram about proclamation of independence. May 30, 1918 